\title{
FEATURES OF JURASSIC DOLERITE INTRUSIONS AT CAPE SURVILLE, LYNWOOD, SINGLE HILL AND MOUNT NELSON, TASMANIA
}

\author{
by David Leaman
}

(with one table, four text-figures and one plate)

Leaman, D.E., 1997 (31:viii): Jurassic dolerite intrusions at Cape Surville, Lynwood, Single Hill and Mount Nelson, Tasmania. Pap. Proc. R. Soc. Tasm. 131: 13-20. https://doi.org/10.26749/rstpp.131.13 ISSN 4703-0080. Leaman Geophysics, GPO Box 320, Hobart, Tasmania, Australia 7001

The intrusive features associated with the Jurassic dolerites of Tasmania are generally well displayed, but rarely is more than one feature visible at any one site. The great range of characters can, however, be reviewed and inspected by visiting only four sites. Each site prevides information which can constrain any hypotheses for mechanisms of emplacement and suggests a multiphase fracture-controlled injection. Keywords: Intrusion, Jurassic dolerite, Tasmania, emplacement.

\section{INTRODUCTION}

Jurassic dolerite intrusions of all scales, bur usually very large, are topographically dominant and geologically ubiquitous across eastern and central Tasmania. Even though many features of the intrusions are well and commonly exposed, it is very rare to find sites or exposures where several characteristic features are present in restricted or accessible areas. Most descriptions of the intrusions and their form, and most theories of emplacement, draw upon a large number of occurrences, few of which are easily visited (for example, Leaman 1975, 1977, 1995, Banks et al. 1989). Further, detailed description of those sites is generally not available, and most comments about intrusions have been given in association with gravity surveys (McDougall \& Stott 1961, Leaman 1972, 1990a, Leaman \& Richardson 1981).

There are, however, four sites (fig. 1) where all of the critical features of dolerite intrusions can be inspected easily; these are Mt Nelson (Leaman 1975, 1976, 1978, 1995), Cape Surville (Leaman 1978, Gulline 1984), Single Hill (Leaman 1975, 1976, 1978, 1995) and Lynwood. Although no one site displays a full set of features, those selected display several aspects of the intrusions and the intrusion process, at all scales, in a small area. No other sites are known which offer this clarity and economy of inspection.

Each of these four sites and the intrusion features found therein are described below. Each is recommended for visitation. These notes are intended as both a guide to the features present and a discussion of their origin, and provide new observations or new interpretation in each case.

The intruded Permian and Triassic rocks are known as the Parmeener Supergroup (Clarke 1989). The lower part, Permian, may be divided into an upper and lower glaciomarine sequence, while the upper part, Triassic-(?)Lower Jurassic, is a terrestrial sequence.

\section{SITE 1: MT NELSON INTRUSION}

The principal exposures are found beside the Southern Outlet near the Olinda Grove intersection and overpass $2 \mathrm{~km}$ south of Davey Street, Hobart. Accessory features are to be seen in and near the Waterworks Reserve, north of

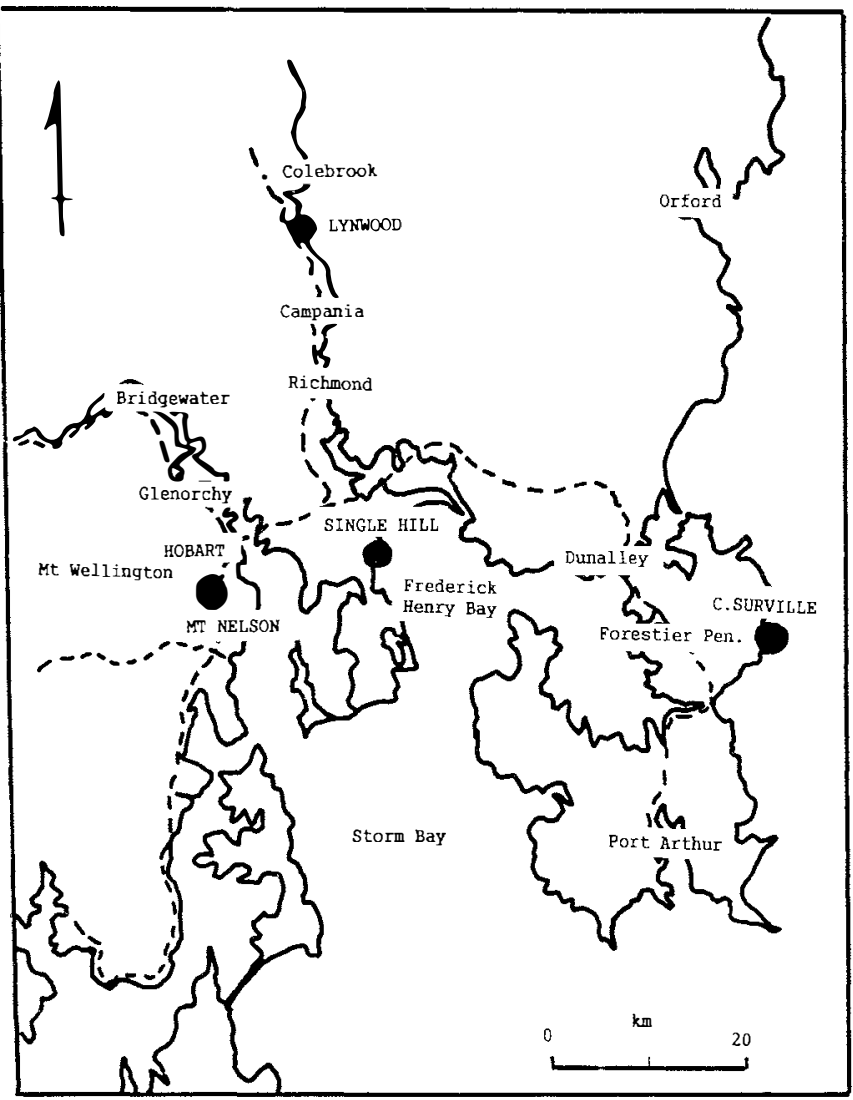

FIG. 1 - Southeastern Tasmania showing the location of the selected sites. Cape Surville is the least accessible.

Tolmans Hill, and along the highway nearer Kingston (fig. 2).

All sites are accessible by car. The Hobart section of the Tasmanian Towns Street Atlas can be used to locate all roads. All the features of the Olinda Grove area can be inspected in less than two hours, but a full day is required to view the entire set of localities indicated.

Elements of this site have been partly illustrated by Leaman $(1976,1978)$ and discussed by Leaman (1995). The details of the relationships and exposures present have not been published previously. 


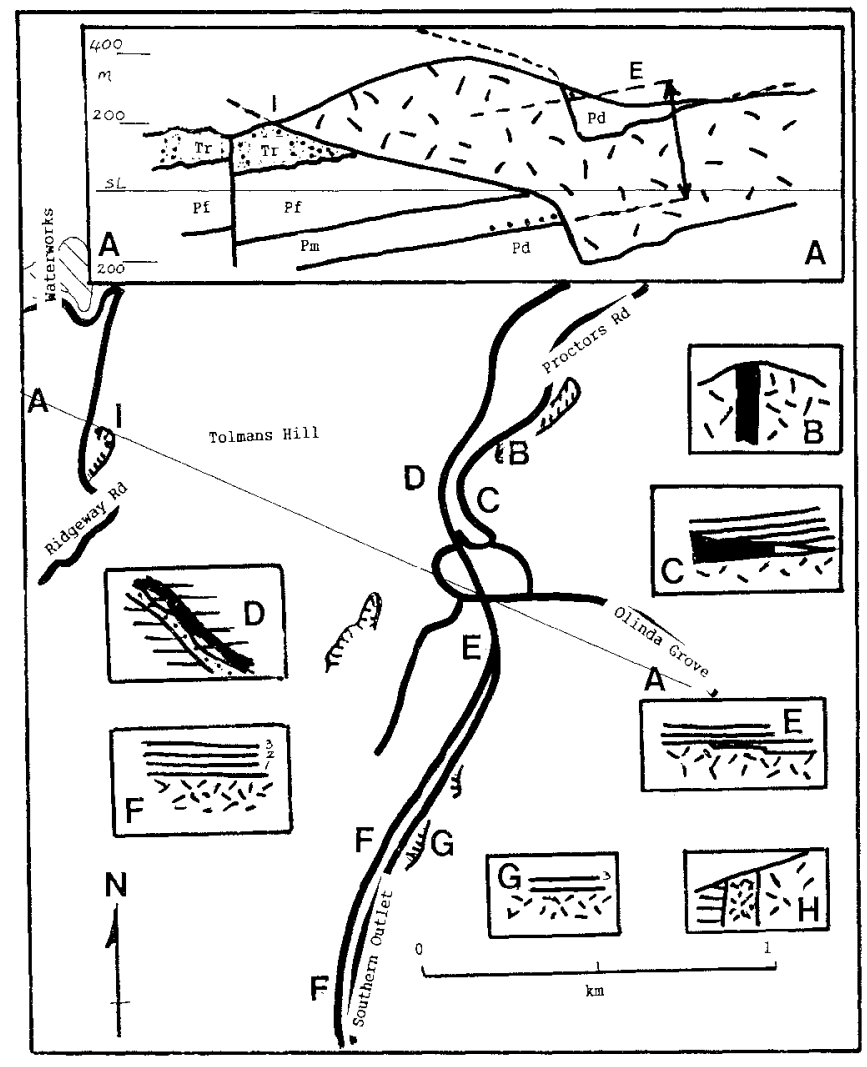

FIG. $2-$ Mt Nelson: Location of intrusive features in the region of Proctors Road, Olinda Grove and the Waterworks. The small, located sketches indicate the features present and the section suggests the regional character of the intrusion. Intruded rocks are shown with dotted or lined patterns; dolerite is shown in black or as random ticks in order to distinguish multiple intrusions.

\section{Major Contacts}

Immediately sourh of the overpass (E, fig. 2), the roof of a dolerite sheet steps from bed to bed through a fossiliferous, calcareous mudstone of Permian age (correlate of Deep Bay Formation, of Farmer 1985, Clarke 1989). Plate 21 in Leaman (1976) and plate 15 in Leaman (1978) show this feature. The overall effect is of low-angle transgression, since concordance is predominant. Sill character is always well displayed and leads to a mistaken view about the shape of large intrusions. The overall discordance of the Nelson intrusion in these exposures amounts to less than $1 \%$ of the thickness of the intrusion. The base of this intrusion is exposed several kilometres to the southeast, across $\mathrm{Mt}$ Nelson near upper Taroona, within the same formation. A regional dip of $5^{\circ}$ and presumed absence of any large-scale faulting suggest an intrusion thickness of over $350 \mathrm{~m}$.

Review of all contacts in the Olinda Grove area, however, indicates an average $10^{\circ}$ rise in the top of the intrusion from west to east, compared with the regional dip of $5^{\circ}$. Thus, the incrusion has transgressed upward across the bedding from the west, with an average differential of $5^{\circ}$. This effect is relatively local, since other exposures up to $1 \mathrm{~km}$ south of Olinda Grove (F, G, fig. 2) display long concordant (sill-type) boundaries (e.g. pl. 20, Leaman 1976; pl. 14, Leaman 1978), some of which are consistent in level and dip, and others of which imply a transgression or fault offser between exposures. All transgression appears to be up from west to east. The section in figure 2 (near $E$ ) shows how the effective dip of the intrusion may exceed regional dips.

\section{Minor Contacts}

North of the overpass the contact is multiply intruded (pl. 22, Leaman 1976), and one intrusion contains a frozen, bulbous nose within the wedge prised open by the magma (C, fig. 2; pl. 8, Leaman 1978). The tip of the wedge (shown unfilled in the diagram) is now filled with highly weathered material, which was probably a gas-enriched fluid containing rock or magma fragments at the time of injection. The apparent sense of injection is up from north to south, due to orientation of the cutting, but the real direction may have been WNW-ESE, based on three-dimensional review of all exposures and relationships. The frozen wedge of incomplete injection (black in diagram) is within the roof of the earlier, major intrusion (patterned). The hydraulic conditions which force this relationship have been discussed by Leaman $(1975,1990 \mathrm{~b})$. This is the only known magma wedge involving the Tasmanian dolerites (compare Mudge 1968). A quarry beside Proctors Road, directly below these exposures, contains a dyke (about $4 \mathrm{~m}$ rhick) of glassy dolerite within very coarse-grained and commonly pegmatitic dolerite $(B$, fig. 2; Edwards 1942, Spry 1962). The upper part of this dyke appears across the highway in a now-filled quarry (D, fig. 2; pl. 23, Leaman 1976; pl. 7, Leaman 1978). Only the upper part of this intrusion is now visible there. Authorities seeking to restore such sites should seek advice about the conservation value of the contents! The dyke west of the road is composite, less than $2 \mathrm{~m}$ thick, and remnants of sedimentary contacts persist between two fine-grained dolerites. The margin of an earlier intrusion has been reintruded in a manner comparable to that observed in the roof top near C (fig. 2).

Comparable compound margins may be found $5 \mathrm{~km}$ south of the overpass, where the major Mt Nelson intrusion has been faulced and the fault subsequently intruded (e.g. $\mathrm{H}, 525400 \mathrm{E}, 5243400 \mathrm{~N}$ ). The second intrusion is rarely more than $15 \mathrm{~m}$ wide and separates Permian siltstones from very coarse-grained dolerite. Neither sedimentary rock nor earlier dolerite is thermally affected in any significan manner. This contact extends $N-S$, whereas the main intrusion margin nearby trends approximately E-W.

\section{Internal Features}

Systematic variations in texture can be found within the Tolmans Hill region (fig. 2) but no banding or layering has been recognised. This suggests that the main Mt Nelson intrusion was due to a single large magma pulse. This character is also true of the Mt Wellington intrusion, and the early pecrological studies, such as those by Edwards (1942), which were based on both the Mt Nelson and Mt Wellington sheets, have led to assumprions about the differentiation and intrusion of dolerite bodies which are nor universally applicable (contrast site 3 , Single Hill).

The road cuttings south of the overpass ( $F$, fig. 2) demonstrate the quality of the rock, its fresh colouring and the impact of subhorizontal jointing on water flow and weathering. There is little evidence of systematic, thermally 
developed jointing parallel to the contacts in this intrusion, and the subhorizontal joints are due to relaxation. These extensive, large-scale joints always disrupt all other joint types, are slightly curved and occur at angles generally less than $15^{\circ}$ to present average landform slopes but in the same sense. Elastic rebound from removed loading is implied. Other examples of this joint type can be seen in Ridgeway Road, above site I (fig. 2).

Exposures around Tolmans Hill display columnar joints with slightly curved faces up to $4 \mathrm{~m}$ across (e.g. I). Other, local jointing is imposed upon the columnar pattern, and the change from platy joints to large columns, whose long axes are normal to the margin of the intrusion in each case, can be seen in Waterworks Quarry near the contact (I). This contact dips south at about $20^{\circ}$. The joint relationships found near intrusion margins were described by Leaman (1978). Platy joints, or mini-columns, are not a universal feature of Tasmanian intrusions; they are pronounced in some areas and not others. The reason for this variation is not known but may be a function of dolerite intrusion stage, magma composition, country rock hydrology and heat transfer, or intrusion size. East Tasmanian dolerites, such as those north of Swansea and within the Fingal-St Marys region, are compositionally and texturally distinctive and regularly display platy joints well in from the margin (Leaman \& Richardson 1981, Leaman 1978). Ambient temperatures may also have been important — factors which may be influenced by the presence and cooling of earlier intrusions or the ability of the intruded medium to conduct or transfer heat. Platy joints (or bow-tie, festoon or other complex patterns) are rarely seen where the rocks of the lower marine, Lower Parmeener Supergroup have been intruded, as at Mt Nelson.

Examples of the varied weathering style of Tasmanian dolerites and of the local instability associated with some conjunctions of thermal and tectonic joint orientations and road alignment may be found along Ridgeway Road. These provide good examples of the engineering issues involved. This road tends to wind up the hillside and cuttings along it tend to generate an array of face orientations with respect to the many joint sets displayed. Several of these combine, in some places, to face and dip toward the road. Large-scale collapse has occurred wherever weathering is also extreme, or has been influenced by one joint set often the low-angle, elastic relaxation joints.

\section{Metamorphic Effects}

The pebbly mudstone intruded by the dolerite has been metamorphosed, and the distinctive colour banding developed reflects slight variations in composition (especially calcareous content) and texture. Within a few metres of the contact, the rock has been converted into a calc-silicate hornfels, with generation of diopside and, in places, wollastonite. Marked metamorphic effects rarely extend more than $3 \mathrm{~m}$ from the roof contact, although lesser changes may be more extensive (compare B-D, fig. 4, Single Hill, below).

\section{Overall Intrusive Form}

The base of the Mt Nelson intrusion lies within the Deep Bay Formation, at Taroona, and within Triassic rocks, on the northwest side of Tolmans Hill (I). The section (fig. 2) indicates that stratigraphic control within the WaterworksTolmans area is insufficient to establish the dilation across the intrusion within Tolmans Hill, but the units exposed are consistent with an intrusive thickness of about $350-400 \mathrm{~m}$ (for dilation rules, Leaman 1972).

Early analyses of the Mt Nelson intrusion placed a feeder system for the major sheet in the region near the axis of $\mathrm{Mt}$ Nelson (Leaman 1972, 1975). Subsequent gravity analyses linked with aeromagnetic data have shown, however, that the feeder system is large and located within the RidgewayWest Tolmans area (Leaman 1990a, 1992, fig. 13). Granophyric differentiates of the dolerite in the Ridgeway area and many small intrusions in the Ridgeway and Proctors Road areas are consistent with a feeding centre there. The overall sense of magma passage is up from southwest to northeast. The three-dimensional relationships of the entire intrusion can be satisfied only by a fracture and intrusion rising in this manner.

\section{SITE 2: CAPE SURVILLE INTRUSION}

The large dolerite intrusion at Cape Surville was, until recently, only visible from the sea but not readily accessible. It remains almost inaccessible to touch, but locations which allow visual appraisal can now be reached overland.

Cape Surville is the most easterly promontory of the Forestier Peninsula and overlooks some of the wildest seacliff coastline in Tasmania. The principal exposures, up to $300 \mathrm{~m}$ of vertical section on Deep Glen Bluff, are visible from the Cape (fig. 3).

Access to the site from vehicular roadheads requires a minimum walk of about one hour on good tracks,

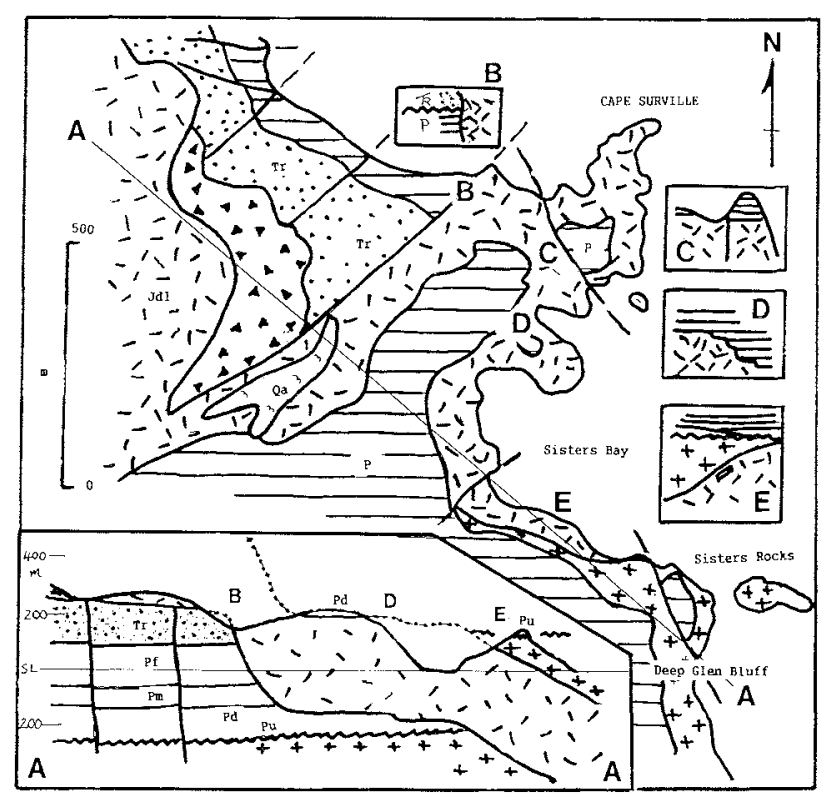

FIG. 3 - Cape Surville: Location of intrusive features in the region of Cape Surville and Deep Glen Bluff. The small, located sketches suggest the features present and the section shows how these are related. The geological basemap is a complete revision of Gulline (1982). Dolerite is shown by a tick pattern, Devonian granites by a cross pattern, Triassic rocks by dots, Permian rocks by horizontal lines and Pleistocene talus by triangles. 
maintained by the Hobart Walking Club with the approval of Forestry Tasmania. The nearest roadhead for a car is at 576500 E, $5243050 \mathrm{~N}$ on Schofields Road, reached by Hylands-1 side road from Murdunna: a four-wheel-drive vehicle, using the same basic access, can reach $578950 \mathrm{E}$, $5242100 \mathrm{~N}$ (Tasmap 1:25000 Murdunna). Allow an extra half-hour for the walk from the car terminus.

\section{Major Contacts}

Cape Surville itself is composed largely of dolerite, with two small caps of Permian rocks (C, fig. 3; pl. 11, Gulline 1984) that include correlates of the Malbina Formation and Risdon Sandstone. Much more strongly bedded, calcareous, finergrained formations underlie these units, but most can only be observed on a crestal "island" south of the cape (D, fig. 3). This is visible in the middle distance in plate 1. Dolerite transgresses through these finer-grained units in the manner described at Mt Nelson. Metamorphic and colour changes are also comparable in these calcareous and fossiliferous rocks, which are probable correlates of the Deep Bay Formation.

The principal intrusive feature in this area is exposed in the cliffs of the north face of Deep Glen Bluff. A smoothly curving dolerite sheet contact arcs upward from sea level, with an average dip of about $25^{\circ}$ (E, fig. 3; pl. 1; pl. 21 , Leaman 1978; pl. 10, Gulline 1984). From sea level to an elevation of abour $120 \mathrm{~m}$ this intrusion is wholly within Devonian granite. Above this, the dolerite enters nearly horizontal Permian rocks. The almost-planar unconformity is well exposed. Although at least four granitoid variants are seen at Deep Glen Bluff, the principal exposure lies within adamellite.

The contact is nowhere disrupted and is nor influenced by any subvertical jointing or faulting. Fractures which parallel the contact occur within the granite. The magma has clearly followed a fracture and the granite complex has reacted as a homogeneous medium.

\section{Minor Contacts}

One aberration may be observed near the contact just below the unconformity. A trapezoidal block of granite no more than $3 \mathrm{~m}$ thick has been included in the intrusion ( $\mathrm{E}, \mathrm{frg} .3$ ). This parting of the intrusion to allow less than $2 \mathrm{~m}$ of dolerite above a block has been termed a xenolith (Leaman 1975), while the style of intrusion splitting has been termed a leaf of intrusion (Francis 1982, Leaman 1995). Since the roof contact has not provided the included block - there is no offset of the margin to allow keying of the inclusion then the base must be the imperfect face. Since the fracturing and intrusion process is dynamic and subject to hydraulic constraints determined by viscosity and crystallisation, the splitting to form the leaf clearly occurred very early in the injection process. The first magma has passed above the block and the remainder is below it. The rapid chilling of such a thin intrusive split or leaf would have prohibited further injection near the margin. There is no evidence for multiple injection or layering in this intrusion, and the hydraulic interconnection of both rapidly cooling leaf and main intrusion mass has lifted the detached fragment. This well-displayed leaf is relatively small, when compared with the leaves described by Francis (1982) or McGregor \&

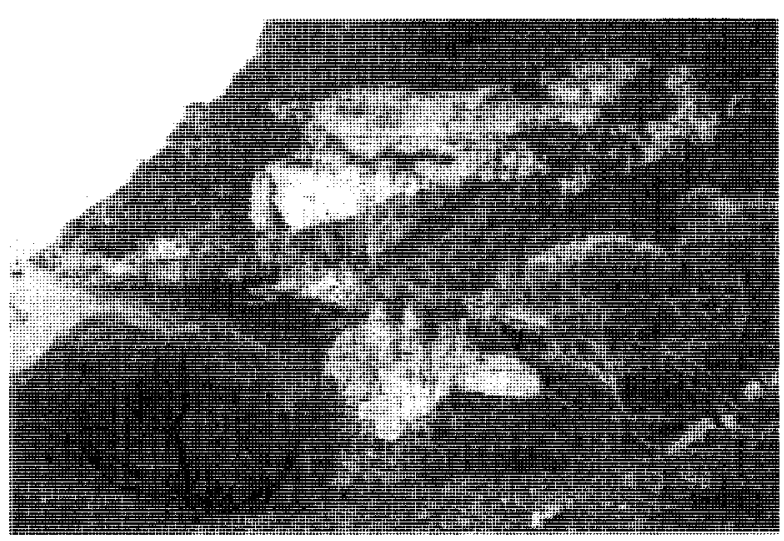

PLATE 1

View of Deep Glen Bluff and the Cape Surville intrusion. The smoothly curling contact of the roof within granite may be contrasted with the irregular transgressive forms within Permian rocks [foreground]. This view is from site $C$ (fig. 3).

McGregor (1948). Other leaves are known (Blackmans Bay South, Banks et al. 1989:376; Boyer south and Mt Direction, Leaman 1975).

\section{Overall Intrusive Form}

The entire display is unique ( $\mathrm{pl.1}$ ); it is possible to observe changes in intrusion style above and below the basin unconformity, with characters predicted by both Carey (1958) and Leaman (1975), although examples of the nature of the fracture could not be provided.

The Surville-Deep Glen Bluff intrusion also presents enough information to infer its thickness, even though the base is not exposed. Northeast of Cape Surville, the intrusion is terminated in a complex faulted contact (B, fig. 3). The post-intrusion fault displacement is small, probably no more than $15 \mathrm{~m}$, and represents the offset on faults which separate Deep Glen Bluff and the Sisters Rocks. Similar small displacements $(5-15 \mathrm{~m})$ along the coastline north of Cape Surville disturb the virtually conformable boundary between Late Permian marine and Early Triassic terrestrial deposits.

It is possible, therefore, to match stratigraphic levels on each side of the intrusion quite closely; the basal Permian unconformity approximates the level of the basal Triassic disconformity. The dilation of the intrusion, or its thickness, equals that of the entire Permian sequence in this location. Since the Triassic disconformity lies about $350 \mathrm{~m}$ above the sub-Permian unconformity in the Deep Glen area then the intrusion must be about this thickness.

Possible inaccuracies in this estimate arise from small faults in the area - possibly about $10 \mathrm{~m}$, variations in the total thickness of the Permian sequence west of Deep Glen Bluff - possibly $25 \mathrm{~m}$, and any associated variations in the unconformity surface. This surface is irregular, as seen in Deep Glen Bluff (E, fig. 3), and does include at least one minor onlap to the unconformity and another within $15 \mathrm{~m}$ above it. The inurusion may be as thick as $385 \mathrm{~m}$.

The intrusive sheet rises from ESE to WNW (at Deep Glen Bluff) and SSE to NNW (toward Cape Surville), before stepping upward and out of the Permian rocks just west of Cape Surville (in the style of Leaman 1975). This 
indicates a feeder south of Sisters Rocks offshore. Gulline (1984) refers to the exposure within granite as the feeder. The stepped zone (B, fig. 3 ) is a faulted contact, but better access has permitted some revision of the mapping of Gulline (1982), and this is also shown in figure 3.

\section{SITE 3: SINGLE HILL INTRUSION}

Single Hill is an isolated hill located between Lauderdale and Seven Mile Beach (fig. 4). A series of superb exposures of its eastern face is available along the shores of Frederick Henry Bay. The Hobart section of the Tasmanian Towns Street Atlas can be used to locate this site. As many of these exposures lie within the tidal range, and there is some active beach formation, some small intrusions and parts of the roof of the major intrusion are only exposed at low tide or after storm erosion. The site is very accessible, and inspection of its contents requires allocation of at least half a day.

\section{Major Contacts}

The regional setting is that of the roof of a major intrusion with a steep elbow upward to the west, away from the coast and in to the heart of the hill. The roof of the main intrusion is exposed. The northern side occurs north of a small fault (between 10 and $15 \mathrm{~m}$ displacement) at $A$ (fig. 4), and to the south as a major dipping contact D-E (the elbow) parallel to a small sheet found in the cliff at $\mathrm{B}$ (i.e. approx. $50^{\circ} \mathrm{N}$ ). This, coupled with the dyke extension pattern, indicates the overall stress field (N-S extension). Both lateral pillars of the intrusion, whether concordant top to the north or discordant arm to the south, reveal compound and multiple intrusion. The roof is subconcordant near A but is more irregular near G. A roughly triangular sectional wedge of Permian rocks has been preserved between the intrusion roof and the land surface (from $\mathrm{C}$ to $\mathrm{E}$ ). The rocks within the intrusion roof were clearly stressed and fractured by tensile forces (see Minor Contacts below).

\section{Minor Contacts}

Leaman (1975) described en-echelon dyke fingers extending from the main intrusion below, which indicate a horizontal extension, overall, of about $0.6 \mathrm{~m}$ within a zone $2 \mathrm{~m}$ wide. These fingers are located at $\mathrm{D}$ (fig. 4). These small dykes are very glassy, with thin $(<5 \mathrm{~mm})$, irregular, protruding tips, which extend more than a metre as greenish veins.

A small intrusive sheet can be seen in the cliff nearby (B, fig. 4). This feature was illustrated in plates 24 and 25 in Leaman (1976) and provides the best single and complete example of dilation associated with a dolerite intrusion. Both horizontal and vertical dilation (approx. 90 and $170 \mathrm{~mm}$ respectively) can be defined. Beds, or intrusion wall irregularities, can be matched across the intrusion (pl. 24, Leaman 1976). The overall view (pl. 25, Leaman 1976) shows how the incrusion has arched upward following a fracture in these well-bedded rocks, which are correlates of the Deep Bay Formation. A large granite pebble has been split by the intrusion. The plate shows that a large piece of limestone has been included in the upper part of the intrusion. This fragment is much altered and may have been carried within the magma; it is not derived from any

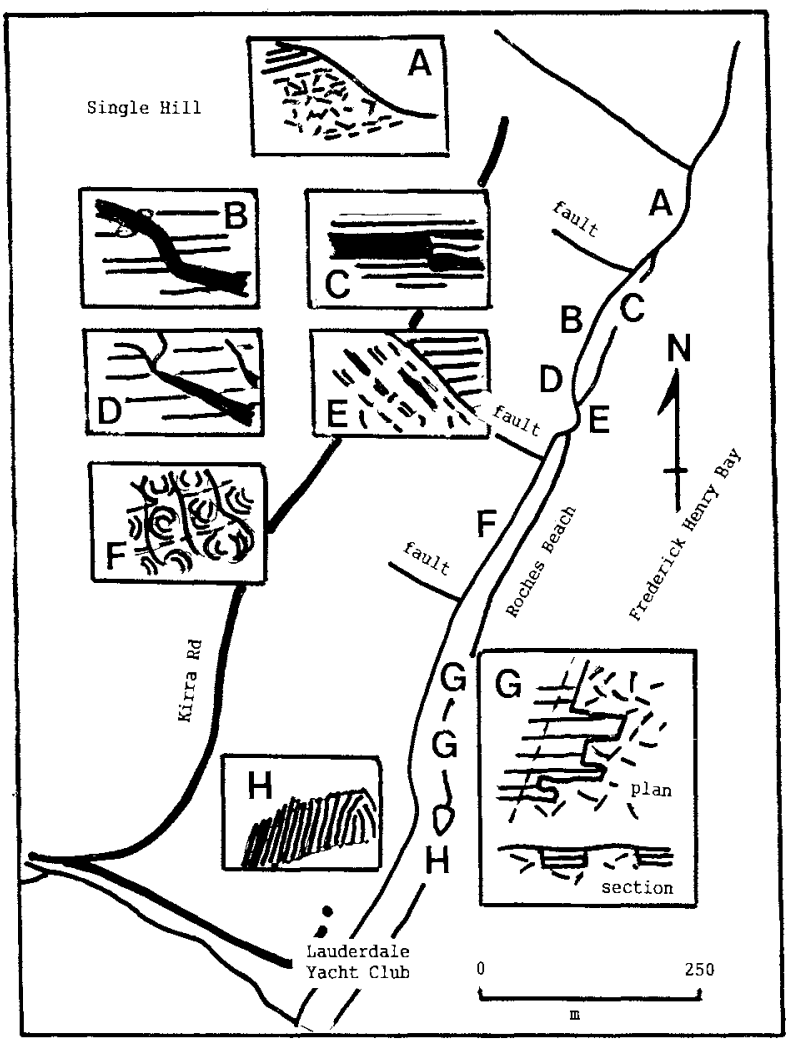

FIG. 4 - Single Hill: Location of intrusive features in the Roches Beach-Single Hill area. The small, located sketches suggest the features present. Intruded rocks are shown with a lined pattern; dolerite is shown in black or as random ticks in order to distinguish multiple intrusions.

part of the current exposure and does not have the form of a keyed leaf, since the overall thickness and dilation associated with the intrusion, including it, rather than of dolerite alone, are constant. This small sheet is one of many exposed in this area. Most others are thinner and much more concordant, but all display aspects typical of major sheets. One intrusion demonstrates that deformation may occur in the intruded rocks, where the intrusion changes shape abruptly (C, fig. 4); another shows that contemporaneous small faults - now almost entirely devoid of dolerite - did transfer dolerite to another level, and that these faults only apply to the units adjacent to the zone intruded. Beds above and below the intruded horizons are usually free of fracturing (C).

The complex character of the intrusion roof, within typical, more siliceous and thickly bedded Permian siltscones, is shown along the beach at $\mathrm{G}$ (fig. 4), mostly within the tidal range (average sea level dotted in figure). All contacts are subvertical, and there are variations in the elevation of the roof. Each zone is a subrectangular block. Jointing found near the contacts has a platy form, where the short axes are parallel to the roof and the long axis is normal to it. Some swirling character (curved, festoon and bow-tie joints) is often present ( $\mathrm{H}$, fig. 4), which may reflect block and roof corners or changes in elevation. Variations in thermal conditions were clearly important. This irregular roof effect has been observed in a strongly bedded, but otherwise homogeneous, lithology of the Fern Tree Group. The more concordant characters described 
above are associated with the much more heterogeneous Deep Bay Formation.

Cooling columns of increasing size, which often display rounded faces or rounded corners, can be observed within the roof of the intrusion at $A, E$ south and $F$ (fig. 4).

\section{Internal Features}

Marked layering parallel to the roof can be observed, irrespective of the attitude of the roof. The intruded dolerite in every case is normal contact zone fine-grained dolerite, while the layers contain coarse-grained material which is granophyric in composition (Everard in Leaman 1976). Many coarse layers have chilled margins, and the fracture patterns are also consistent with intrusion of granophyres into a crystallised but possibly warm main intrusion. The nature of contacts and texture is shown in plates 14 and 15 of Leaman (1976). The northern dolerite roof (A, fig. 4) contains numerous joints subparallel to the subconcordant roof contact, and this joint type, of thermal origin (Leaman 1978), may well have controlled later injection. Layering of the type exposed here, although involving less extreme differentiates, was first recorded in an intrusion drilled in Glenorchy (Leaman 1976). Similar layered dolerite has been observed in other areas (e.g. Cape Raoul, south of Port Arthur), but not all intrusions (compare Mt Nelson, Cape Surville) are "layered" or multiple. The layering is also apparent in the discordant elbow section of the intrusion at $E$, where the overall form is more irregular but essentially parallel to the margin.

\section{Metamorphic Effects}

Different degrees of metamorphism may be observed in the roof at G and B-D (fig. 4). At G the intruded rock is a pebbly, siliceous siltstone, and hardening and joint formation is restricted to within about $0.6 \mathrm{~m}$ of the contact (horizontal or vertical). At $\mathrm{B}-\mathrm{C}-\mathrm{D}$ the intruded rock is a fossiliferous calcareous mudstone with beds of interspersed limestone. Diopside imparts a characteristic green colour, calcite in many fossils has been recrystallised, and wollastonite appears in the limier beds. Metamorphic effects extend up to $10 \mathrm{~m}$ from the roof of the main intrusion and are slightly more extreme than any observed at Mt Nelson.

The Single Hill site also contains fine examples of dolerite weathering, including spheroidal weathering with the release of large cobbles to the beach (F).

\section{Overall Intrusion Form}

Faulting produces a sampling of the main intrusion. G-H (fig. 4) lie close to the intrusion roof and the rock is generally fine-grained. Some coarser layers may be found where outcrop permits. The fault block containing $\mathrm{F}$ is composed entirely of medium-coarse grained dolerite. There is no suggestion of layering or multiple intrusion, and the composition and texture indicate that $\mathrm{F}$ lies about 80 $100 \mathrm{~m}$ below the roof of the intrusion. The dolerite at $\mathrm{E}$ is comparable to that at $\mathrm{G}-\mathrm{H}$ but is a transgressive stage from the sheet roof beneath B-D. This roof is fully exposed at A.

\section{SITE 4: LYNWOOD INTRUSION}

Lynwood homestead is located midway between Campania and Colebrook, along the Colebrook main road in the Coal River Valley, and built upon a rounded hill with thin brown soils and a glassy, platy-jointed dolerite, which intrudes the Upper Triassic Coal Measures. The landform is distinctive. A quarry beside the road allows inspection of part of the roof of the intrusion and the complex interior (Tasmap 1:25000 map Bains, 533700E, 5285100N).

Bubble-shaped features have been recognised in the roof of those intrusions which were relatively close to the Jurassic surface. Most of these occur where faulting produced narrow grabens in a terrain resembling a basin-and-range province. The largest collection of these bubble-shaped features occurs in the Coal River Valley between Campania and northern Colebrook. Two have been quarried. All intrude Upper Parmeener Supergroup (Triassic--(?)Jurassic rocks) and their style was indicated by Leaman (1975, fig. 2). Apart from the bubble form - now reflected in rounded, bulbous hills with little soil cover - the heart of the bubble represents atypical dolerite. Jointing, of thermal origin, is very irregular and tangled, much as in the entablature of complex lava flows. The rock is fine-grained or glassy throughour and intensively veined with calcite, chlorite or zeolites. In normal intrusions, only major joints contain small amounts of these minerals but, in the bubbles, these minerals are common to dominant. Weathering is also extensive, and much travertine is present.

Other fine examples of this intrusive style occur on the south coast, at Lion Rock, and in the Derwent Valley, near Hamilton and Ouse.

\section{SUMMARY OF FEATURES}

Table 1 indicates the range and type of features which can be observed at each site.

The table suggests that Single Hill offers the most complete single demonstration. It provides many fragmental pieces of evidence at all scales, and it is the only site to display large and small features. The small structures are complete. Although an array of joint types is exposed, some better examples of festoon and bow-tie joints occur elsewhere in Tasmania (east coast dolerites from Swansea to Douglas River, north coast dolerites near Devonport).

The most important site in terms of regional perspective and overall form of the large intrusions is at Cape Surville. It is the only place in the Tasmanian province where basement and cover relationships are visible in section and no inference is necessary. The intrusions displayed at the four sites constrain any intrusion theories. The Single Hill and Cape Surville intrusions show that injection followed a fracture, and the Mt Nelson intrusion shows that the fracture was wedged open by the magma. All intrusions show that bedding surfaces modified the form of the fracture. The inrrusions at Single Hill and Mt Nelson were multiphase, with pronounced layering produced in the Single Hill intrusion. Later intrusions were controlled either by marginal fractures in the earlier intrusions or by the primary fracture. No change is stress field is indicated. All joints of thermal origin have orientations and frequencies which reflect either the shape of the incrusion margin or distance from it. 
TABLE 1

Features observed at each site

\begin{tabular}{|c|c|c|c|c|}
\hline & Mt Nelson & Single Hill & Surville & Lynwood \\
\hline \multicolumn{5}{|l|}{ Intrusive forms } \\
\hline complete intrusion & - & $\mathrm{x}$ & - & - \\
\hline partial intrusion & $\mathrm{x}$ & $\mathrm{x}$ & $\mathrm{x}$ & $\mathrm{x}$ \\
\hline intrusion leaf & - & $\mathrm{x}$ & $\mathrm{x}$ & - \\
\hline injection nose & $\mathrm{x}$ & - & - & - \\
\hline large intrusion & $\mathrm{x}$ & $\mathrm{x}$ & $\mathrm{x}$ & - \\
\hline small intrusions & $\mathrm{x}$ & $x$ & - & - \\
\hline sill forms & $\mathrm{x}$ & $\mathrm{x}$ & $\mathrm{x}$ & - \\
\hline transgressive forms & $\mathrm{x}$ & $\mathrm{x}$ & $\mathrm{x}$ & $\mathrm{x}$ \\
\hline roof bubble & - & - & - & $\mathrm{x}$ \\
\hline fracture control evidence & - & $\mathrm{x}$ & $\mathrm{x}$ & - \\
\hline dilation evidence & $\mathrm{x}$ & $\mathrm{x}$ & $\mathrm{x}$ & - \\
\hline contact deformation & - & $\mathrm{x}$ & - & - \\
\hline within cover rocks & $\mathrm{x}$ & $\mathrm{x}$ & $\mathrm{x}$ & $\mathrm{x}$ \\
\hline within basement & - & - & $\mathrm{x}$ & - \\
\hline fault associations & - & $\mathrm{x}$ & $\mathrm{x}$ & - \\
\hline \multicolumn{5}{|l|}{ Other aspects } \\
\hline multiple intrusion & $\mathrm{x}$ & $\mathrm{x}$ & - & $\mathrm{x}$ \\
\hline layered intrusion & - & $\mathrm{x}$ & - & - \\
\hline contact phenomena & $\mathrm{x}$ & $\mathrm{x}$ & - & $\mathrm{x}$ \\
\hline metamorphic effects & $\mathrm{x}$ & $\mathrm{x}$ & - & $\mathrm{x}$ \\
\hline range of composition & $\mathrm{x}$ & $\mathrm{x}$ & - & - \\
\hline weathering character & $\mathrm{x}$ & $\mathrm{x}$ & - & $\mathrm{x}$ \\
\hline \multicolumn{5}{|l|}{ jointing } \\
\hline thermal & $\mathrm{x}$ & $\mathrm{x}$ & $\mathrm{x}$ & $\mathrm{x}$ \\
\hline platy & - & $\mathrm{x}$ & - & $\mathrm{x}$ \\
\hline curled & - & $\mathrm{x}$ & - & $\mathrm{x}$ \\
\hline columns & $\mathrm{x}$ & $\mathrm{x}$ & - & - \\
\hline fracture fills & $\mathrm{x}$ & $\mathrm{x}$ & - & $\mathrm{x}$ \\
\hline
\end{tabular}

\section{ACKNOWLEDGEMENTS}

I am especially grateful to Richard Hopkins and Marcia Solomon who showed me how to reach Cape Surville and return. Access to this important site depends wholly upon their track-making initiatives.

\section{REFERENCES}

Banks, M.R., Green, D.H., Hergt, J.M. \& McDougall, I. 1989. Jurassic dolerire. Introduction. In Burrett, C.F., \& Martin, E.L. (Eds): GEOLOGY AND MINERAL RESOURCES OF TASMANIA. Geol. Soc. Aust. Spec. Publ. 15: 375-378.

CAREY, S.W, 1958. The isostrat, a new technique for the analysis of the structure of the Tasmanian dolerite. In DOLERITE - A SYMPOSIUM. University of Tasmania, Hobart: $130-164$

Clarke, M.J., 1989. Lower Parmeener Supergroup. In Burrett, C.F. \& Martin, E.L. (Eds): GEOLOGY AND MINERAL RESOURCE OF TASMANIA. Geol. Soc. Aust. Spec. Publ. 15: 295-309.

EDwards, A.B., 1942. Differentiacion of the dolerites of Tasmania J. Geol. 50: 451-480, 579-610.

Farmer, N., 1985. Geol. Atlas 1:50000 Ser. Sheet 88 KINGBOROUGH. Explan. Rep. Geol. Surv. Tasm.: 1105 .
Francis, E.H., 1982. Magma and sediment, 1. Emplacement mechanism of late Carboniferous tholeiite sills in northern Britain. J. Geol. Soc. London 139: 1-20.

Gulline, A.B., 1982. Geol. Atlas 1:50 000 Ser. Sheet 83. SORELL. Dep. Mines Tasm

Gulline, A.B., 1984. Geol. Atlas 1:50 000 Ser. Sheet 83. SORELL. Explan. Rep. Geol. Surv. Tasm.

Leaman, D.E., 1972. Gravity survey of the Hobart District. Bull. Geol. Surv. Tasm. 52.

Leaman, D.E., 1975. Form, mechanism and control of dolerite intrusion near Hobart, Tasmania. J. Geol. Soc. Aust. 22: $175-186$.

Leaman, D.E., 1976. Geol. Atlas 1:50000 Ser. Sheet 82. HOBART. Explan. Rep. Geol. Surv. Tasm

Leaman, D.E., 1977. Geol. Atlas 1:50000 Ser. Sheet 75 BRIGHTON. Explan. Rep. Geol. Surv. Tasm.

Leaman, D.E., 1978. Some thoughts on dolerite intrusions with particular reference to marginal features. Unpubl. Rep. Dep. Mines Tasm. 1978/30.

LEAMAN, D.E., 1990a. Inferences concerning the distribution and composition of pre-Carboniferous rocks in soucheastern Tasmania. Pap. Proc. R. Soc. Tasm. 124: 1-12.

LEaman, D.E., 1990b. Discussion. Gravitational (density) controls on volcanism, magma chambers and intrusions. Aust. J. Earth Sci. 37: 109-110.

LEAMAN, D.E., 1992. Finding Cambrian keys:- An essay in controversy, prospectivity and tectonic implications. Bull. geol. Surv. Tasm. 70: 124-148. 
LEAMAN, D.E., 1995. Mechanics of sill emplacement: comments based on the Tasmanian dolerites. Aust. J. Earth Sci. 42: 151-155.

Leaman, D.E. \& Richardson, R.G., 1981. Gravity survey of the East Coast Coalfields. Bull. Geol. Surv. Tasm. 60

McGregor, M.D. \& MCGregor, A.G., 1948. BRITISH REGIONAL GEOLOGY. The Midland Valley of Scotland. HMSO, London.
McDougall, I. \& STOtT, P.M., 1961. Gravicy and magnetic observations in the Red Hill area, southern Tasmania. Pap. Proc. R. Soc. Tasm. 95: 7-15.

Mudge, M.R., 1968. Depth control on some concordant intrusions. Bull. Geol. Soc. Am. 79: 315-332.

SPRY, A.H., 1962. Igneous activity. In Spry, A.H. \& Banks, M.R. (Eds): THE GEOLOGY OF TASMANIA. J. Geol. Soc. Aust. 9(2): 107-145.

(accepted 13 November 1996) 